INVESTIGATING THE EFFECTIVENESS OF TEACHING METHODS BASED ON A FOUR-STEP CONSTRUCTIVIST STRATEGY*

\author{
Muammer Çalık ${ }^{1}$, Alipaşa Ayas ${ }^{2}$ and Richard K. Coll ${ }^{3}$
}

1: KTÜ Fatih Faculty of Education, Department of Primary Teacher Education, 61335 Söğütlü-Trabzon/TURKEY, e-mail: muammer38@hotmail.com

2: KTÜ Fatih Faculty of Education, Department of Secondary Science and Mathematics Education, 61335 Söğütlü-Trabzon/TURKEY, ayas@ktu.edu.tr

3: Centre for Science \& Technology Education Research, University of Waikato, Hamilton, NEW ZEALAND, RCOLL@,waikato.ac.nz

*: This study was supported by Research Fund of Karadeniz Technical University, Project Number: 2005.116.002.1 


\begin{abstract}
This paper reports on an investigation of the effectiveness of different methods embedded within a four-step constructivist teaching strategies, for the teaching of solution chemistry. A sample consisting of 44 Grade 9 students (18 boys and 26 girls) was drawn purposively from two different classes (22 each) in the city of Trabzon, Turkey. Data collection employed a purpose designed solution chemistry concept test consisting of 17 items, along with student interviews. The findings suggest that using different methods embedded within the four step constructivist teaching strategy enables students to refute alternative conceptions, but does not completely eliminate alternative conceptions.
\end{abstract}

Key wordS: High School/Introductory Chemistry, Chemical Education Research, Analogies/Transfer, Hands-On Learning, Solutions / Solvents, Misconceptions 


\section{INVESTIGATING THE EFFECTIVENESS OF TEACHING METHODS BASED ON A FOUR-STEP CONSTRUCTIVIST STRATEGY}

Solution chemistry plays an important role for further chemistry learning for a variety of and topics such as rate of reaction, equilibrium, and electrochemistry. As a consequence many education research studies have been conducted to explore students' understanding of solution chemistry, and to find ways to overcome student alternative conceptions (1). Studies have concerned topics perspectives such as dissolution, the nature of dissolution process, solubility, energy changes during dissolution, the effect of temperature and stirring on dissolution, the conservation of mass during dissolution, structural characteristics of solutions, types of solution, the depression of vapor pressure, the solubility of a gas in a liquid, the depression of melting points, the relationship between vapor pressure and boiling points, the effect of surface area on dissolution, solutions and their components, and electrolyte and non-electrolyte solutions (2). However, the literature suggests that just identifying and categorizing students' alternative conceptions is not enough on its own (3). Instead we need ways to bring about conceptual change, and research has identified different strategies for conceptual change. Examples reported include: a hypermedia environment that animates dissolution (4), a solution chemistry unit involving students working collaboratively with their chemistry teacher (5), group exploration to inquire about the solubility of salt, sugar, potato flour, baking soda (6), a teaching-learning sequence based on the particle model of solubility (7), a worksheet that contains students' conceptions of conservation of mass during dissolution (8), a worksheet that incorporates students' conceptions of the particulate nature of matter, melting and dissolution, the rate of dissolution, and the amount of the dissolved matter (9), conceptual change text used to refute students' alternative conceptions $(2,10,11)$, the use of analogy in the teaching of conservation of

mass during dissolution process (12), a Model-Observe-Reflect-Explain (MORE) laboratory 
module used to help students revise molecular-level ideas regarding chemical compounds dissolved in water (13) and a constructivist-based teaching model about student understanding of the dissolution of gases in liquids (14). Of these research reports only one focused on whether or not a constructivist based teaching model enables students to store new, more scientific, conceptions in their long term memory. Most reported research employs a single conceptual method or technique to deal with students' conceptions - for example conceptual change, analogy, worksheet, and so on. However, recent research suggests that using just one teaching method to bring about conceptual change may in fact result in new learning difficulties. For example, if we exploit worksheets to help students to develop their conceptual understanding, students may find this boring and this may reduce their motivation (15). Likewise, it is not generally possible to find a course book or curriculum document that incorporates conceptual change text for all topics of study at school. In nay case again students soon become bored with continued reading of conceptual change texts (16). A similar situation applies to the repeated use of analogy as a conceptual change agent (e.g. 17, 18, 19, 20).

In light of the above we propose her that using two or more conceptual change methods or techniques embedded within a four-step constructivist teaching strategy may help students to develop a better conceptual understanding, without adverse side effects such as loss of motivation. Therefore, the present study investigates the effectiveness of the use of several different teaching methods embedded within a four-step constructivist strategy for the teaching of solution chemistry. 


\section{Method}

\section{Sample}

The sample used in this study consisted of 44 Grade 9 students (18 boys \& 26 girls) drawn purposively from two different classes (22 each) in the city of Trabzon, Turkey. Elementary school achievement ranged from 3.36 to 4.85 , with a maximum possible score of 5.00. Some participants were boarders studying with scholarships from the Ministry of National Education. The participants came from a variety of cities across Turkey: Giresun (7 students), Erzurum (3 students), Rize (2 students), Samsun (1 student), Artvin (1 student), Ordu (1 student), Bingöl (1 student) and İstanbul (1 student). The remainder of the sample $(n=27)$ came from Trabzon where the study was conducted.

\section{$\underline{\text { Data Collection }}$}

A multiple method approach was used in order to provide data triangulation $(21,22)$. The methods used included: (a) solution chemistry concept test consisting of 17 items, and (b) student interviews.

The content of a 17-item solution chemistry test is presented below for the target concepts.

\section{Insert Table 1 about here}

Three sample items from the solution chemistry concept test are now represented in more detail:

Item 2. For a solution of sugar in water, which of the following is correct? 
a) Sugar is the solvent and water is the solute

b) Sugar is the solute and water is the solvent

c) Both sugar and water are solutes

d) Both sugar and water are solvents.

Because

Item 6. Some matter (water, ethyl alcohol and olive oil) are added into beakers in the following sequence (where $\mathrm{Z}$ is olive oil, $\mathrm{A}$ is ethyl alcohol, and $\mathrm{S}$ is water). Which of the following illustrates the distribution into beaker, please explain your reason (if you think that none of the drawings is correct, please draw your own figure using the empty beaker presented under $\mathrm{H}$ ).

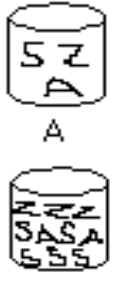

$\mathrm{E}$

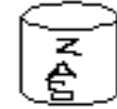

$\mathrm{B}$

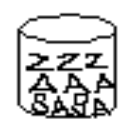

$\mathrm{F}$

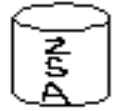

C

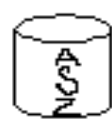

$\mathrm{G}$

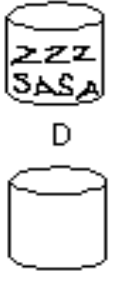

$\mathrm{H}$

Because

Item 13. When crushed and uncrushed salt is added to two glasses of water at the same temperature and in equal amounts, they both dissolve. If the water in the solution is evaporated by heating, what happens? Please explain your answer

The test was initially administered one month before the intervention as a form of pre-test, and the same test was subsequently employed as a post-test after students completed 10 teaching activities across 8 class periods. The same test was re-administered as a delayed post-test 10 weeks after the intervention, to see if any conceptual change was stored in students' long term memory.

Interviews were conducted with six students, two students for each level conceptual change, namely average (S6 \& S9), below average (S8 \& S25) and above average (S16 \& S42)). These students were chosen on the basis of their total conceptual change score for solution chemistry, based on differences in pre-test, post-test and delayed post-test scores. The interviews took 35-40 minutes and the students conducted three tasks about the sugar/water system, olive oil/alcohol/water system and carbonate drink using an injector (i.e., based on items 10, 12, 14, 15, 
$16 \&$ 17). These interviews strived to better understand student reasoning and thus provide a more in-depth understanding that could be gleaned from the concept test alone.

\section{Data Analysis}

Six students (S1, S2, S21, S22, S38 \& S44) did not take part in one of the tests (2 for each test) because of class absences, but what data was gained is still included in the qualitative data analysis.

In analyzing the two-tier items, students' responses were looked at globally, and subsequently classified according to the following criteria: Correct Choice with Sound Understanding (CCSU) (10 points), Correct Choice with Partial Understanding (CCPU) (9 points), No Choice with Sound Understanding (NCSU) (8 points), Incorrect Choice with Sound Understanding (ICSU) (7 points), No Choice with Partial Understanding (NCPU) (6 points), Correct Choice with Specific Alternative Conception (CCSAC) (5 points), Correct Choice (CC) (4 points), Incorrect Choice with Specific Alternative Conception (ICSAC) (3 points), No Choice with Specific Alternative Conception (NCSAC) (2 points), Incorrect Choice (IC) (1 point) and No response or Irrelevant Responses (0 point). Likewise open-ended items, were analyzed using the following criteria: Sound Understanding (4 points), Partial Understanding (3 points), Partial Understanding with Specific Alternative Conception (2 points), Specific Alternative Conceptions (1 point) and No Understanding (0 point). After categorizing each response total test scores were computed and analyzed using conventional statistical tests including one-way ANOVA. Interview data were analyzed thematically looking for commonality of views, and differences in student responses $(23,24)$. 


\section{The context of activities}

The four step constructivist model used as an intervention here consists of: (1) eliciting students' pre-existing ideas, (2) focusing on the target concept, (3) challenging students' ideas, and (4) applying newly constructed ideas to similar situations (see 14, 25, 26, 27). In the first step, a related question is asked to activate students' pre-existing knowledge and to motivate them. In the second step, a designed activity paper is handed out so that students study the related topic in small groups of four students. In the third step, when students complete their activities, they present their results and discuss these with the teacher and peers in a whole-class forum. Next the teacher confirms or disconfirms student knowledge claims and states the scientific explanation. Finally, students are confronted with a different situation in order to reinforce their newly structured knowledge.

\section{Insert Table 2 about here}

\section{$\underline{\text { Results }}$}

\section{Findings from the Solution Chemistry Concept Test}

As can be seen from Table 3, there is a statistically significant difference between groups $(\mathrm{p}<0.05)$ between the pre-test and post-test and between the pre-test and delayed post-test in favor of post-test and delayed post-test $(\mathrm{p}<0.05)$. However, there are no statistically significant differences between post-test and delayed post-test scores ( $\mathrm{p}>0.05)$.

Insert Table 3 about here 


\section{Insert Table 4 about here}

As can be seen from Table 5, whereas about half of students' responses fell into the 'ICSU' category for item 1 in the post-test and delayed post-test, three tenths of responses were categorized as 'CCSU' for item 2 in the post test. Moreover, for item 4 whilst about one fifth of students' responses were categorized as 'CCSU', seven tenths of them fell into the 'CCPU' category in the delayed post-test. In the case of item 6, whereas nearly two fifths of responses were classified as 'CCPU' in the post-test, approximately the same percentage of them fell into 'ICSAC' category in the delayed post-test. For item 7 while a quarter of the responses were classified as 'CCPU' about half of were classified as 'ICSAC'. About three quarters of the responses were categorized as 'CCPU' in both post- and delayed post-test in case of item 8, and for item 9 about half of the responses fell into the same category.

\section{Insert Table 5 about here}

As can be seen from Table 6, for item 3 while approximately two fifths of the sample responses were categorized as 'SU' in the post-test, and about the same in the 'PU' category. In the case of item 5 three tenths were labeled 'PU' and about half 'NU' category in both the postand delayed post-test. Nearly three fifths of the responses were classified as 'PU' in both the post- and delayed post-test for item 11, and about three fifths in the same category in both the post- and delayed post-test for item 13 .

\section{Insert Table 6 about here}




\section{Findings from student interviews}

\section{a. Sugar in water system}

The principal questions students responded to are categorized in terms of their similarities and differences in Table 7.

\section{Insert Table 7 about here}

To track student response's reasons in depth follow-up questions also were used. For the question 'Do you mean that if a solution is formed, it must consist of a solid and a liquid?' S6 said that since he frequently encounters solid-liquid solutions in daily life. During interviews students often referred to 'melting'. To clarify the students' view of any difference between melting and dissolution processes a probe question 'is there any difference between melting and dissolution processes?' was asked. S6, S16, S25 and S42 commented out that for melting to occur a higher temperature is required and that a phase change occurs, but that two matters for dissolution two materials, a 'solute' and a 'solvent' are necessary. S8 noted that during melting process the material loses some of its chemical properties, but that during dissolution one material retains its own properties, and is mixed with the other. To better understand S8's views, 'what kind of change occurs here?' was asked. He answered that this is a physical change and said that dispersion of sugar into water is an example for such change. To explore S8's views of 'chemical change' he was asked 'what do you mean by chemical change?' and he responded that this involved a phase change for ice, which then lost its properties. In a similar way, S9 said that melting involves is a change from a solid to a liquid; whereas dissolution involves is the decomposition of molecules. He also said melting requires a solid substance, and dissolution requires a liquid. To follow up this explanation, she was asked 'do you think that a liquid is a pre- 
requisite for dissolution process?' and she went on to explain that it is not a pre-requisite, and noted that liquid and gaseous substances also can be a 'solute' or 'solvent'. A more full example of an interview extract is provided below to show student thinking about dissolution:

R: What happens when you add sugar into a beaker of water?

S6: Dissolution takes place

R: What do you mean by 'dissolution'?

S6: Both solid's and liquid's particles mix with each other fully

R: How do they mix with each other?

S6: They mix homogenously and disperse everywhere equally

R: Do you mean that if a solution forms, it must consist of a solid and a liquid?

S6: No, no... Gas-gas, liquid-gas, solid-gas, etc. are also possible

$\mathrm{R}$ : Why do you think that the mixture occurs between a solid and liquid?

S6: Since we frequently encounter a solid-liquid solution in our daily life, this is a common habit

.........

R: You have just referred to the word 'melting'. Is there any difference between melting and dissolution?

S6: For melting temperature is a pre-requisite and a phase change occurs, however, two materials named 'solute' and 'solvent', are at least necessary for dissolution.

$\mathrm{R}$ : Do you have any idea about why the term melting often is used instead of dissolution?

S6: That is a common habit. In fact I use 'dissolution' concept in school. However, I prefer using 'melting' in my daily life.

Two other students were probed as to their ideas about chemical and physical change:

R: Could you explain which of the change occurs here, physical or chemical change?

S25: Chemical change because sugar in water can be obtained by means of chemical ways

$\mathrm{R}$ : What do you mean by 'chemical way'?

S25: For example... if we heat sugar in water, sugar stays at the bottom of the beaker. As a result, water vaporizes and sugar is re-obtained

R: Do you have any ideaa about physical change?

S25: Physical change means combustion of sugar... that is it cannot be re-obtained

$\mathrm{R}$ : Is there any difference between chemical and physical change?

S25: If a matter can be re-obtained it is chemical change; if not it is physical one

Another part of interview procedure comprised the use of drawings to discover how students visualize sub-microscopic level phenomena. Some student drawings are displayed below:

\section{Insert Figure 1 about here}


To explore S6's views, she was asked 'what do you mean by gaps within water?'. She said that when we add an instrument that measures weight, some bubbles give off. When the researcher requested her to explain further information about this statement, she said that as a cube sugar is dropped into water, some bubbles appear, this means that there are gaps within water particles. Later, the question 'do you consider that the gaps within water are pre-requisite for dissolution process?' was asked and here she said that it is not a pre-requisite:

R: Please explain your drawn figure

S16: Homogenously... They mix with each other homogenously

R: How does sugar mix with water?

S16: Of course, homogenous mixture

$\mathrm{R}$ : Does your drawn figure reflect this?

S16: Yes... It reflects homogenous mixture. I distributed sugar and water particles equally

To probe S16's views about the total mass of solution she was asked 'what do you mean by gaps?'. She said that when a cube of sugar is added into water, there are some bubbles at the top of the beaker, and that this means that there are gaps within water particles. Likewise, when other students were asked to explain their responses further, S6 and S25 commented on differences between mass and weight, and said that since a closed beaker was used, there is no loss of mass. S8 and S9 referred here to the conservation of mass, and stated that the amount of each initial component is the same if they can be re-obtained. Moreover, S16 and S42 repeated their earlier statements:

R: Do you think that the total mass of solution is equal to the initial masses of components (sugar and water)?

S8: Total mass conserves

R: Please explain your response

S8: Both of the total masses of them are the same, because water cause to lose the properties of sugar and there is a matter loss

$\mathrm{R}$ : Could you give more information about your statement?

S8: There is a conservation of mass law... thus, the amount of each initial component is the same if they are re-obtained... if we melt sugar into water, a chemical change occurs 
An response to the question 'If you vaporize water in solution fully, what happens?' from

S42 is provided below:

R: If you vaporize water in solution fully, what happens?

S42: Water vaporizes and sugar stays at the bottom as initial condition

R: Please explain the reason why water vaporize rather than sugar

S42: Sugar is solid... water can vaporize easier because it is liquid... liquid has a vaporization feature that discriminates it from the others.

$\mathrm{R}$ : Could you give further information about this?

S42: Since water is in liquid phase, its vaporization is easier than a solid one that must be liquefied and then vaporized

When asked 'What do you mean by the term solvent?' and 'What do you mean by the term solute'?', S25 stated that a solvent makes a solute decompose into its own ions. However, when he remembered the analogy used in the intervention, he changed his mind as seen in Table 7. Similarly S6, S9, S16 and S42 said that a solvent determines the phase of solution, and S8, S9, S16 and S42 said that unless a solute is available, a solution can not form. An exception tothis view is presented in the following interview with S16:

$\mathrm{R}$ : Taking into consideration sugar in water, which one is solute and which one is solvent? S16: Sugar is solute and water is solvent $\mathrm{R}$ : What do you mean by the term solvent?

S16: The amount of solvent in solution is more than that of solute... the solvent gets solute decomposed to either its own ions or molecules

$\mathrm{R}$ : Could you give further information about this?

S16: Solvent determines the phase of solution since its amount is more than that of solute

$\mathrm{R}$ : What do you mean by the term solute?

S16: The amount of solute in solution is less than that of solvent and... it disperses into solvent $\mathrm{R}$ : Could you explain this?

S16: How the opposition party is necessary for democratic environment, unless a solute exists, a solution does not take place

To follow up the question 'after heating one of the beakers please explain what you observed', a second question, 'what kind of energy increases with an increase in temperature' was asked. All of the interviewees responded that this was kinetic energy. A subsequent question 'if kinetic energy boasts what happens?', resulted in S6, S9, S16 and S42 saying out that particles move faster so that rate or the amount of interaction increases. S8 and S25 similarly mentioned 
that particles move faster, so that rate of dissolution is enhanced. However, S25 also said that the size of particle matters. An excerpt from S8's interview is below:

R: (After heating one of the beakers) Please explain what you observed S8: Quietness

$\mathrm{R}$ : What kind of energy increases with an increase in temperature?

S8: Kinetic energy

R: If kinetic energy increases, what happens?

S8: Particles move faster so that rate of dissolution is enhanced

$\mathrm{R}$ : Please explain how temperature affects the amount of the dissolved solute in solution (for a solid into a liquid)

S8: The amount of the dissolved matter... no change

$\mathrm{R}$ : What factor affects the solubility amount?

S8: Temperature

R: Please explain your response

S8: If I heat it, this is a chemical change... of course the amount of sugar is influenced with an increase in temperature... namely, the amount of the dissolved matter modifies

$\mathrm{R}$ : In this case, how temperature affects the amount of the dissolved solute in solution?

S8: The amount of the dissolved solute reduces with an increase in temperature

R: Please give further information about this?

S8: The amount of the solute staying at the bottom entails and the amount of the dissolved solute increases, as well

When asked about the electrical conductivity of sugar in water, after the intervention S25

changed his initial view and said that sugar in water can conduct electricity. A follow-up question

'What do you mean by ion?' was asked and S6, S9, S16 and S42 stated that ions, which can be

positive or negative or mobile charges, conduct electricity. S25 said that decomposing a solute to

form its own molecules is ionization. An excerpt about this is provided below:

R: Do you consider sugar in water conducts electricity?

S25: Sugar in water does not conduct electricity.... No, no... Sugar in water conducts electricity. I

was also confused this question in the test.

R: Please explain your response

S25: Since sugar decomposes to its own ions it does not conduct electricity. In fact, all solutions conduct the electricity

R: Could you give a solution example that conducts the electricity?

S25: Salt in water

$\mathrm{R}$ : What is necessary for electricity conductivity?

S25: It must decompose to its own ions

R: What do you mean by ions?

S25: Molecules in solute... decomposing a solute to its own molecules means that it is ionization 


\section{$\underline{\text { b. Oliver oil/Alcohol/Water System }}$}

The students responses to the questions about the olive oil/alcohol/water system were classified based on their similarities and differences and these are summarized in Table 8 .

\section{Insert Table 8 about here}

A typical responses to questions 'after adding a little ethyl alcohol into water please explain what happens', and 'how does alcohol disperse into water?', is shown below:

R: Do you think that adding a little ethyl alcohol changes color of water?

S6: No, no...

R: Please explain what happens?

S6: Ethyl alcohol disperses

R: How does alcohol disperse into water?

S6: Homogenously and we cannot see it with the naked eye

After pouring a little olive oil into ethyl alcohol in water, students were asked to explain what happens. All of them said that olive oil goes up the top of the beaker. To follow-up S25's explanation as to why olive oil goes up the top of the beaker, he was asked 'which of the heterogenic or homogenous mixture is correct for solution?'. He said out that a solution is a homogenous mixture, and relinquished his earlier idea saying the olive oil system as in fact a heterogenic solution. Likewise, S16 said olive oil does not mix with ethyl alcohol and water homogenously, because there are no gaps between olive oil particles. S16 described the last mixture as emulsion. An anecdote is showed in the following:

R: (after pouring a little olive oil into ethyl alcohol in water) please explain what happens? S25: Olive oil goes up the top of the beaker $\mathrm{R}$ : Why does the olive oil go up the top of the beaker?

S25: A heterogenic solution occurs and does not possess equal feature in everywhere... olive oil is lighter, therefore, goes up. Ethyl alcohol and water mix with each other homogenously $\mathrm{R}$ : Which of homogenous or heterogenic is correct for a solution?

S25: We cannot use both homogenous and heterogenic together... since we cannot see ethyl alcohol and water by the naked eyes, it is a homogenous... solution is homogenous mixture $\mathrm{R}$ : Do you think that the only reason is density for olive oil?

S25: No... Olive oil mixes with neither ethyl alcohol nor water 


\section{Insert Figure 2 about here}

S16 and S25 said that they drew olive oil $(Z)$ at the top of the system, because its density is lowest of any substance in the system. Likewise, S42 said out that although olive does not dissolve in ethyl alcohol or water, it can dissolve in another substance that has similar properties. When asked 'why he drew water (S) and ethyl alcohol (A) side by side', S8 said that this was due to the formation of a heterogenic mixture, and draw another figure (S8-II):

R: Please explain your figure?

S8: Ethyl alcohol interacts with water and yields a heterogenic mixture. Since olive oil's density is less than those of the others, it stays at the top and forms a heterogenic mixture

R: Why did you draw water (S) and ethyl alcohol (A) side by side?

S8: Since ethyl alcohol mixes with water heterogenially, it can be drawn as another form... the only possible figure is not this (S8-I)

R: Would you like to re-draw this figure?

S8: Of course... they are a fragmented manner... but olive oil always goes up (he drew 8-II)

$\mathrm{R}$ : Why does olive oil always goes up?

S8: it is possible that olive oil can go down in another mixture... but here it goes up in regard to water and ethyl alcohol

R: What do you mean by this figure?

S8: Since a heterogenic mixture emerges, it is a dispersed manner

When asked about the total mass of the olive oil/ethyl alcohol/water system, S9 said that since a physical change occurs here, the total mass of the system is conserved. But S6, S16 and S42 said that total mass of the system changes because of gaps, and when asked "what do you mean by gap?', they said that whilst the gap between solid particles is the least, gaps between gas particles are much larger. S8 talked of loss of matter, and upon further probing said that since a chemical change occurs here, the properties of the substances is modified, meaning their total mass also changes:

R: Do you think that the total mass of olive oil/ethyl alcohol/water system is equal to the initial masses of components?

S42: As I mentioned before, ethyl alcohol mixes with water homogenously. Since ethyl alcohol fills in the gaps into water, there is a little difference so that the total mass of the system is not equal to addition of initial masses of components... there is a decrease in total mass 
$\mathrm{R}:$ Do you mean that gap is a pre-requisite for dissolution process?

S42: No, no... it is not necessary

$\mathrm{R}$ : What do you mean by 'gap'?

S42: The gap in structure of water is already available... Ethyl alcohol fills into this gap by mixing with water... like a solid phase

$\mathrm{R}$ : Please give further information about this

S42: Whilst the gap between solid particles is the least distance, one between gas particles is the longer distance

$\mathrm{R}$ : Please explain your response

S42: Ethyl alcohol fills the gaps into water... when we consider solid phase of matter, there are molecular gaps amongst particles. Since water is a liquid phase, its molecular gap is more so that ethyl alcohol can locate there

When the students were asked to answer "why they did not incorporate in olive oil either solute or solvent?', S6, S9, S16, S25 and S42 said that olive oil does not mix with ethyl alcohol and that because of this no solution is formed meaning we cannot label anything as a solute or solvent for this system. Similarly, S8 said that neither solute nor solvent can be identified because there is no a solution or homogenous mixture. When asked 'as if a solution occurred, what would you explain 'solute' and 'solvent'. For the concept 'solvent' S42 also addressed that solvent determines phase of solution. For the concept 'solute' whilst S6 referred to homogenous dispersion, S42 stated that solute is necessary for dissolution process:

R: Please identify the solute and solvent in this system

S6: Water is the solvent again. Sine ethyl alcohol dissolves into water, it is the solute

$\mathrm{R}$ : Why did you incorporate in olive oil either solute or solvent?

S6: Neither olive oil mixes with ethyl alcohol nor a solution yields, thereby, it is not labeled as solute or solvent... also, it stays as it is

$\mathrm{R}$ : When do you mention from solute and solvent?

S6: A solution or homogenous mixture exists

R: What do you mean by the term 'solvent'?

S6: The amount of the solvent in solution is more

$\mathrm{R}$ : What do you mean by the term 'solute'?

S6: The amount of solute in solution is less than that of solvent

\section{Discussion}

Statistical analysis suggests that using these different methods within a four-step constructivist teaching model not only helps students to store their conceptions in their long-term memory, but also is effective in reducing students' alternative conceptions (except for Items 5, 6 
\& Item 7). Since there are no statistically significant differences between post- and delayed posttest scores, this suggests that the activities used here have been stored in the students' long-term memory rather than their short-term memory $(29,30,31,32)$. It is interesting to consider why the students failed to understand some of the phenomena in Table 5. This may result from them not reading the question carefully, because the students encounter related but different examples from those used in the test.. Similarly, students' responses to items 6 and 7 may stem from the structure of the related activities. We tried to get students to use their newly structured knowledge in another situation and, for example, devised conceptual change text for the dissolution of sugar in water and an analogy for salt in water, and did not focus on the olive oil/ethyl alcohol/water system. Likewise, for item 7 we used a worksheet incorporating hands-on activities adapted from Johnson and Scott (8) and Taylor and Coll (12) and these activities concentrated on solid-liquid solutions. Finally, we assumed that since different methods were used here to get students to achieve their conceptual understanding, they should have been able to apply this knowledge to another situation. But it seems this assumption is not supported for some items.

For dissolution, even after intervention some of the students (e.g., S25) held alternative conceptions. Similarly, all of the interviewees referred to melting instead dissolution. This suggests that these students still hold dual conceptions for dissolution as reported in the literature (33, 34, 35), something confirmed directly in S6's interview. Interestingly, for the olive oil/ethyl alcohol/water system the students described only the scientific concept and none mentioned the melting. This is probably because all of components are liquids, meaning melting is not an obvious connection to make. Student drawings reflect view so a homogenous mixture - apart from S8's figure for olive oil/ethyl alcohol/water, which indicates a dilemma between his preexisting knowledge and the scientific view (Figure 2 for S8-I) This alternative conception reemerged when he was asked 'Why did you draw water (S) and ethyl alcohol (A) side by side?'. 
This suggests that using different methods within the four-step constructivist teaching strategy created disequilibrium, but S8 has not achieved equilibrium in his cognitive system. Similarly, in the case of the electrical conductivity of solutions S25 firstly responded that sugar in water does not conduct electricity, and then changed his idea saying it conducts electricity. Such a situation is consistent with other work (36) which notes different types of knowledge in student's cognitive system, and that there is a competition in which the strongest retained conceptions dominates.

The main alternative conception identified when discussing the conservation of mass during dissolution is the idea of a gap between molecules or particles. The explanations suggests that these students cannot link their theoretical knowledge with this novel situation. For example, they thought that since some bubbles appear at the top of a beaker after adding a cube sugar, this means that there must be gaps between particles or molecules. This suggests that students have misinterpreted the particulate nature of matter with respect to dissolution.

After the intervention, almost all of the students progressed in terms of their conceptual understanding for the concepts of 'solution', 'solute' and 'solvent', and they tended to use scientific explanations. Specifically, S8 used and described the concepts of 'solution', 'solvent' and 'solute' properly, but he referred to a heterogenic mixture, and could not distinguish this from solute and solvent.

Some students (i.e. S9 and S25) labeled physical changes as chemical changes even though their explanations reflected physical change. This mostly likely is just difficulty in using appropriate terminology rather than misunderstanding of the concepts. Student's difficulties with item 13 may result from alternative conception about vaporization (e.g. S9) (37). On the other hand, it may mean they cannot distinguish between a mixture and a compound (38).

Some of the students seemed to lack the ability to understand the effect of temperature on solubility of a solid in a liquid, even though the activity used explicitly showed how temperature 
influences solubility at the sub-microscopic level. When probed with follow-up questions, almost all of the students used ideas consistent with accepted scientific knowledge. However, some of the students were still confused as to whether or not an increase in temperature increases the amount of the dissolved solute. S25, for example, referred to particle size possibly as a result of an alternative conception about the particulate nature of matter (i.e., to move faster the size of particle must be small). For the electrical conductivity of solutions, the main issue seems to be the concept 'ion' or 'ionization'. Even though an analogy was used here (28) illustrating several solution examples, some students' alternative conceptions seem stable. This is consistent with the idea that if alternative conception is well-structured or 'hard-core', it is resistant to change (e.g., $39,40,41,42)$.

In conclusion, it seems that using different teaching methods within a four step constructivist teaching strategy helps reduce students alternative conceptions to some extent, but does not fully eliminate alternative conceptions $(14,30,43)$.

\section{Appendix: Sample teaching design}

Eliciting students' pre-existing ideas: What do you firstly remember about the concepts 'solute', 'solvent' and 'solution'? Please explain your answer

\section{Focusing on the target concept:}

Equipment: Beaker, Water, Salt and Oil

Directions: You will answer previous question if you carry out the following directions and questions.

1. Please take three beakers and add the same of the salt $(1 \mathrm{~g})$ into each beaker

2. Then pour $40 \mathrm{ml}$ water into two of the beakers and stir them (Beaker B and Beaker C)

3. Later add a bit of oil $(5 \mathrm{ml})$ into Beaker $\mathrm{C}$

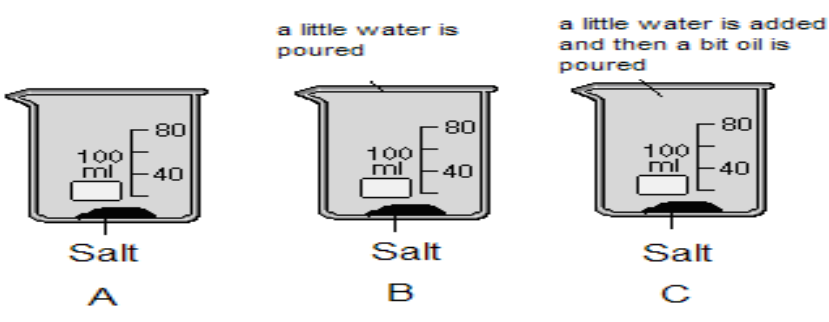

- Please compare Beaker A with Beaker B. Is there any similarity and difference? 
- Please compare Beaker B and Beaker C in terms of their similarities and differences?

- Which of the phase changes (solid-liquid-gas) can be observed in each beaker? Please explain your response

- Which of the beakers indicates the only phase (homogenous dispersion)? Please explain your response

- In the foregoing mixtures (Beaker B and Beaker C), which of the added matters has more amount? Please explain your response

- Could you explain the concepts 'solute', 'solvent' and 'solution' based on your foregoing experiences?

Challenging students' ideas: In this step, teacher introduces the opposition party and the party in power at Turkish National Assembly (TBMM). The number of the party in power is more than that of the opposite party and the party in power has more effective role in coming up with an agreement point. Therefore, it 'outweighs' the opposition at the Turkish National Assembly. However, unless the opposition party is available, a democratic environment does not occur. Also, even if the number of the opposition is less, it checks the work done by the party in power and acts as a control mechanism. Of course, these affairs occur in Turkish National Assembly (TBMM). When we consider the concepts 'solute', 'solvent' and 'solution', the amount of solvent is more and determines the phase of the solution like the party in power. The amount of the solute is less, but it is necessary for constituting a solution like the opposition party. The place where solute and solvent disperse homogenously with one another is solution like Turkish National Assembly (TBMM).

Then teacher presents the subsequent analogical mapping by confirming or disconfirming their generated notions. Later, he/she demonstrates the transparent paper of types of solutions. 


\section{Analogical mapping of solution and its components}

\begin{tabular}{|l|l|l|}
\hline Analogue Feature & Comparison & Targeted Feature (Conception) \\
\hline $\begin{array}{l}\text { The number of the party in power is more } \\
\text { than that of the opposite party and the } \\
\text { party in power has more effective role in } \\
\text { coming up with an agreement point }\end{array}$ & Compared with & $\begin{array}{l}\text { the amount of solvent is more and } \\
\text { determines the phase of the solution }\end{array}$ \\
\hline $\begin{array}{l}\text { Even if the number of the opposition part } \\
\text { is less, it checks the works done by the } \\
\text { part in power as a control mechanism. }\end{array}$ & Compared with & $\begin{array}{l}\text { The amount of the solute is less, but it is } \\
\text { necessary for constituting a solution }\end{array}$ \\
\hline $\begin{array}{l}\text { The place where both opposite party and } \\
\text { the party in power are together is Turkish } \\
\text { National Assembly }\end{array}$ & Compared with & $\begin{array}{l}\text { The place where solute and solvent disperse } \\
\text { homogenously with one another is solution }\end{array}$ \\
\hline $\begin{array}{l}\text { The number of the party in power } \\
\text { The number of the opposition party }\end{array}$ & Not compared with & $\begin{array}{l}\text { Particles of solvent because solvent } \\
\text { contains millions particles during } \\
\text { dissolution process }\end{array}$ \\
\hline $\begin{array}{l}\text { The place where the opposite party and } \\
\text { party in power are together is Turkish } \\
\text { National Assembly (TBMM) }\end{array}$ & $\begin{array}{l}\text { Narticles of solute because solute also } \\
\text { includes millions particles during } \\
\text { dissolution process thes are enormous }\end{array}$ \\
\hline
\end{tabular}

\section{Transparent Paper of Types of solutions}

\begin{tabular}{|c|c|c|c|c|}
\hline \multicolumn{2}{|r|}{ Solute } & \multicolumn{2}{|c|}{ Solvent } & Solution \\
\hline Solid & $\begin{array}{c}\text { Sn (Tin) } \\
\text { Zn (Zinc) } \\
\mathrm{C} \text { (Carbon) or Ni (Nickel) } \\
\mathrm{Au}(\text { Gold) } \\
\end{array}$ & Solid & $\begin{array}{l}\mathrm{Cu} \text { (Copper) } \\
\mathrm{Cu} \text { (Copper) } \\
\mathrm{Fe} \text { (Iron) } \\
\text { Ag (Silver) } \\
\end{array}$ & $\begin{array}{c}\text { Bronze } \\
\text { Bell metal } \\
\text { Steel } \\
\text { Gold whose degree is lower }\end{array}$ \\
\hline Liquid & $\begin{array}{c}\mathrm{Hg} \text { (quicksilver) } \\
\mathrm{CH}_{3} \mathrm{COOH} \text { (Acetic Acid) } \\
\text { Water Steam }\end{array}$ & $\begin{array}{l}\text { Solid } \\
\text { Liquid } \\
\text { Gas }\end{array}$ & $\begin{array}{c}\mathrm{Ag} \text { (Silver) } \\
\left.\mathrm{H}_{2} \mathrm{O} \text { (Water }\right) \\
\text { Air }\end{array}$ & $\begin{array}{c}\text { Teeth filling (amalgam) } \\
\text { Vinegar } \\
\text { Humidity air }\end{array}$ \\
\hline Gas & $\begin{array}{c}\mathrm{H}_{2} \text { (Hydrogen gas) } \\
\mathrm{CO}_{2} \text { (Carbon dioxide) } \\
\mathrm{O}_{2} \text { (Oxygen) }\end{array}$ & $\begin{array}{l}\text { Solid } \\
\text { Liquid } \\
\text { Gas }\end{array}$ & $\begin{array}{l}\mathrm{Pt} \text { (Platinum) } \\
\mathrm{H}_{2} \mathrm{O} \text { (water) } \\
\mathrm{N}_{2} \text { (Nitrogen) }\end{array}$ & $\begin{array}{l}\text { A mixture of hydrogen and platinum } \\
\text { Carbonate drink (cola etc) } \\
\text { A mixture of oxygen and nitrogen }\end{array}$ \\
\hline
\end{tabular}

\section{Applying newly constructed ideas to similar situations:}

Direction: On the basis of the earlier steps, please use your newly structured knowledge to novel situation. For the following examples, please identify solution(s) and then state their components.

Pickle water

Acetone and nail polish

Lime tea

Carbonate drink

Cologne

Drink made of yoghurt and water

Soda

Milk
Laundry water (water with $\mathrm{HCl}$ )

$$
\text { Air }
$$

Bell metal

Steel

Vinegar

Chalk with water

Mud with water

Lemonade 


\section{$\underline{\text { References }}$}

1. Çalık, M.; Ayas, A.; Ebenezer, J.V. J. Sci. Educ. Tech. 2005, 14(1), 29-50

2. Çalık, M.; Ayas, A.; Coll, R.K. Int. J. Sci. Math. Educ., 2007, 5(1), 1-28

3. Schmidt, H.J. Sci. Educ., 1997, 81, 123-135.

4. Ebenezer, J. J. Sci. Educ. Tech. 2001, 10, 73-91.

5. Ebenezer, J.V.; Gaskell, P.J. Sci. Educ., 1995, 79(1), 1-17.

6. Kaartinen, S.; Kumpulainen, K. Learn. Instr., 2002, 12, 189-212.

7. Kabapınar, F.; Leach, J.; Scott, P. Int. J. Sci. Educ., 2004, 26(5), 635-652.

8. Johnson, K.; Scott, P. Res. Sci. Tech. Educ., 1991, 9(2), 193-212.

9. Chang, M.M.; Grabowski, B. Constructivist and Objectivist Approaches To Teaching Chemistry Concepts to Junior High School Students. Annual Meeting of the American Educational Research Association, 1994, New Orleans.

10. Pınarbaşı, T.; Canpolat, N.; Bayrakçeken, S.; Geban, Ö. Res. Sci. Educ. (in press)

11. Uzuntiryaki, E.; Geban, Ö. Instr. Sci., 2005, 33, 311-339.

12. Taylor, N.; Coll, R. Austr. Sci. Teac. J. 1997, 43(4), 58-64.

13. Tien, L.T.; Teichert, M.A.; Rickey, D. J. Chem. Educ. 2007, 84(1), 175-181.

14. Çalık, M.; Ayas, A.; Coll, R.K.; Ünal, S.; Coştu, B. J. Sci. Educ. Tech. (in press)

15. Demircioğlu, H.; Atasoy, Ş. J. Buca Educ. Faculty (in press)

16. Dole, J. A. Read. Writ. Quar. 2000, 16, 99-118.

17. Duit, R. Sci. Educ. 1991, 30, 1241-1257.

18. Huddle, P. A.; White, M. W.; Rogers, F. J. Chem. Educ. 2000, 77(7), 920-926.

19. Orgill, M.; Bodner, G. Chem. Educ.: Res. Prac. 2004, 5(1), 15-32.

20. Thiele, R. B.; Treagust, D. F. J. Res. Sci. Teac. 1994, 31, 227-242.

21. Harrison, A.G.; Treagust, D.F. Sci. Educ. 2000, 84, 352-381. 
22. Guba, E.G.; Lincoln, Y.S. Fourth generation evaluation. Newbury Park, CA: Sage, 1989.

23. Merriam, S.B. Case Study Research in Education. San Francisco: Jossey-Bass, 1988.

24. Yin, R.K. Case Study Research Design and Methods, $2^{\text {nd }}$ ed.; San Francisco: Sage, 1994.

25. Çalık, M.; Ayas, A. Asia-Pac. For. Sci. Lear. Teac. 2005, 6 (2), Article 6 www.ied.edu.hk/apfslt/

26. Çalık, M.; Ayas, A.; Coll, R.K. Asia-Pac. For. Sci. Lear. Teac. 2006, 7(1), Article 4 www.ied.edu.hk/apfsit/

27. Çalık, M.; Ayas, A.; Ebenezer, J.V. Sci. Educ. (submitted)

28. Fortman, J. J. J. Chem. Educ. 1994, 71(1), 27-28.

29. Glynn, S. M.; Takahashi, T. J. Res. Sci. Teac. 1998, 35(10), 1129-1149.

30. Hynd, C.; Alvermann, D.; Qian, G. Sci. Educ. 1997, 81, 1-27

31. Palmer, D.H. Sci. Educ. 2003, 87, 663-684.

32. Tsai, C.C. J. Sci. Educ. Tech. 1999, 8(1), 83-91.

33. Çalık, M.; Ayas, A. J. Res. Sci. Teac. 2005, 42(6), 638-667.

34. Gilbert, J.K.; Osborne, J.R.; Fensham, P.J. Sci. Educ. 1982, 66, 623-633.

35. Pines, A.L.; West, L.H.T. Sci. Educ. 1986, 70, 583-604.

36. Stavy, R. Int. J. Sci. Educ. 1990, 12(5), 501-512.

37. Coştu, B.; Ayas, A. Res. Sci. Tech. Educ. 2005, 23, 73-95.

38. Coştu, B.; Ünal, S.; Ayas, A. Distinguishing Mixtures and Chemical Compounds: A Clay Activity. 18th International Conference on Chemistry Education, August 3-8, 2004, Istanbul, Turkey.

39. Banerjee, A.C. J. Chem. Educ. 1995, 72(10), 879-881.

40. Barrow, G.M. J. Chem. Educ. 1994, 71(10), 874-878. 
41. Lakatos, I. Falsification and the Methodology of Scientific Research Programmes. In Criticism and the Growth of Knowledge; Lakatos, I., Musgrave, A., Eds.; Cambridge University Press, Cambridge, UK, 1970, pp 91-196.

42. Nakhleh, M.B. J. Chem. Educ. 1992, 69(3), 191-196.

43. Guzzetti, B. J.; Williams, W. O.; Skeels, S. A.; Wu, S. M. J. Res. Sci. Teac. 1997, 34(7), 701719. 

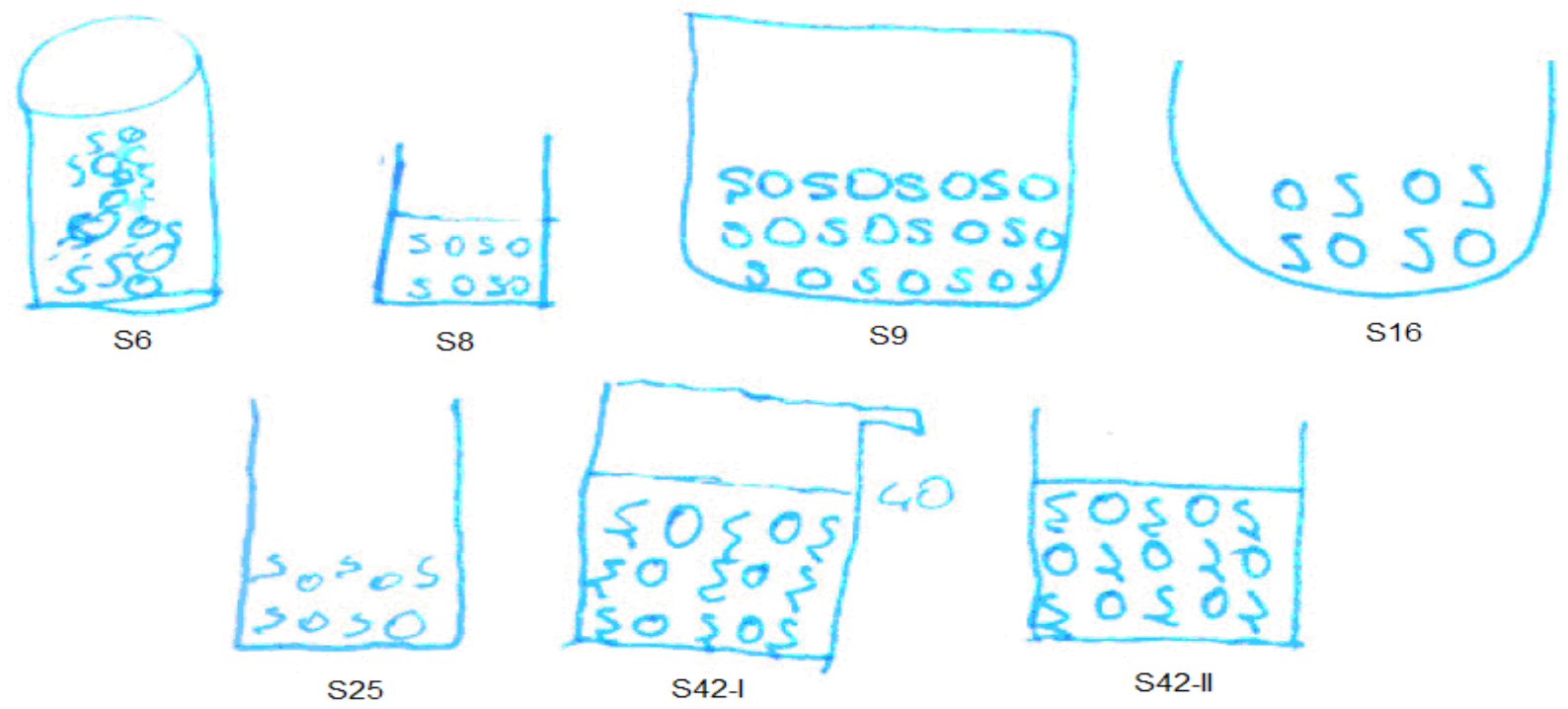

Figure 1. Students' drawings on how they could see 'sugar' and 'water' particles at submicroscopic level

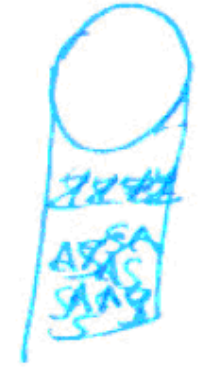

So
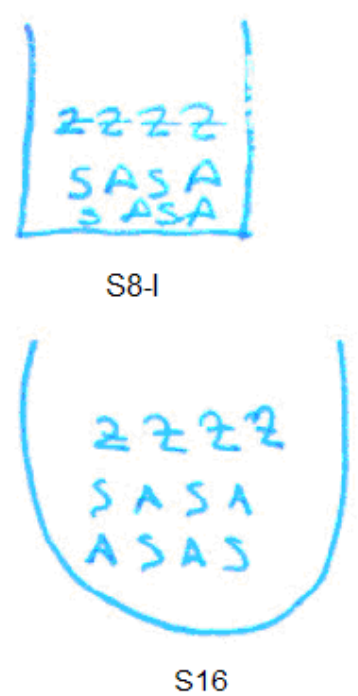

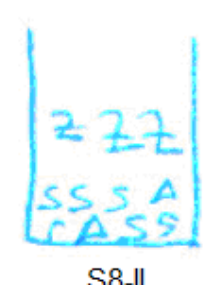

S8-II

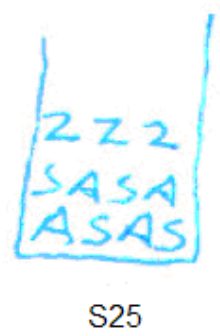

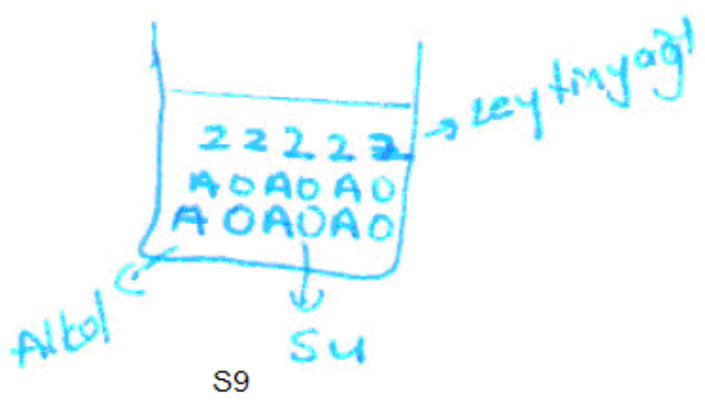

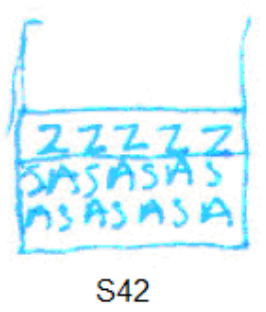

Figure 2. Students' drawings on how they could see 'olive oil', 'ethyl alcohol' and 'water' particles at sub-microscopic level 
Table 1 . The content of a 17-item solution chemistry test

\begin{tabular}{|c|c|c|}
\hline Item number & The targeted concept(s) & Type of question \\
\hline Item 1 , Item 9 & Dissolution & Two-tier question \\
\hline $\begin{array}{l}\text { Item } 2, \text { Item } 3, \\
\text { Item } 5\end{array}$ & Solution and its components & $\begin{array}{l}\text { Item 2-- two-tier question, Item } 3 \\
\text { and Item } 5 \text {-open-ended question }\end{array}$ \\
\hline Item 4 & $\begin{array}{l}\text { Electrolyte and non-electrolyte } \\
\text { solutions }\end{array}$ & Two-tier question \\
\hline Item 6 & Dissolution, solution, solute and solvent & Two-tier question \\
\hline Item 7 & $\begin{array}{l}\text { Conservation of mass during dissolution } \\
\text { process }\end{array}$ & Two-tier question \\
\hline Item 8 & $\begin{array}{l}\text { Dissolution, Unsaturated, saturated and } \\
\text { supersaturated solutions }\end{array}$ & Two-tier question \\
\hline Item $10^{*}$ & $\begin{array}{l}\text { The effect of stirring process to } \\
\text { dissolution process }\end{array}$ & Open-ended question \\
\hline Item 11 & $\begin{array}{l}\text { The effect of temperature to dissolution } \\
\text { process }\end{array}$ & Open-ended question \\
\hline Item $12 *$ & $\begin{array}{l}\text { The effect of surface area to dissolution } \\
\text { process }\end{array}$ & Two-tier question \\
\hline Item 13 & $\begin{array}{l}\text { Dissolution and conservation of mass } \\
\text { during dissolution process }\end{array}$ & Open-ended question \\
\hline Item $14 *$ & $\begin{array}{l}\text { The effect of pressure to solubility of a } \\
\text { gas into a liquid }\end{array}$ & Two-tier question \\
\hline Item $15^{*}$ & $\begin{array}{l}\text { The effect of temperature to solubility } \\
\text { of a gas into a liquid }\end{array}$ & Two-tier question \\
\hline Item $16^{*}$ & $\begin{array}{l}\text { Unsaturated, saturated } \\
\text { supersaturated solutions }\end{array}$ & Open-ended question \\
\hline Item $17 *$ & Dilute and concentrated solutions & Open-ended question \\
\hline
\end{tabular}

*: These items were published elsewhere, therefore, the rest one is presented in the current paper. 
Table 2. The activities embedded with four-step constructivist teaching strategy

\begin{tabular}{|c|c|c|c|c|}
\hline Activities & Step 1 & Step 2 & Step 3 & Step 4 \\
\hline $\begin{array}{l}\text { Activity } 1 \text { of } \\
\text { 'dissolution' concept }\end{array}$ & \multirow{8}{*}{ 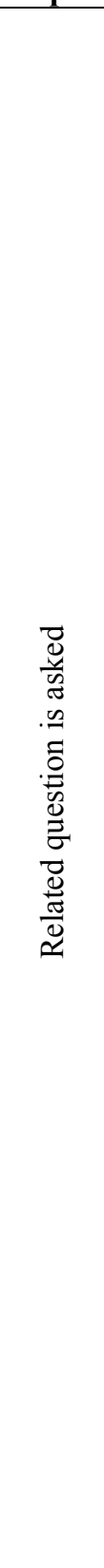 } & $\begin{array}{l}\text { Conceptual } \\
\text { change text }\end{array}$ & $\begin{array}{l}\text { The best and the worst friend analogy } \\
\text { and the related analogical mapping } \\
\text { table }\end{array}$ & \multirow{8}{*}{ 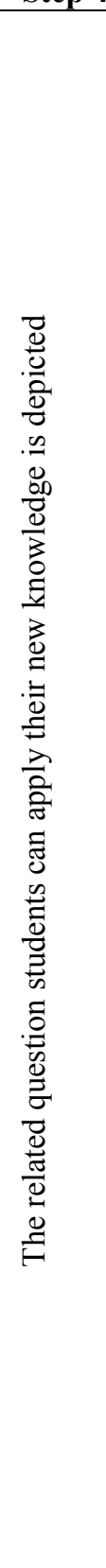 } \\
\hline $\begin{array}{l}\text { Activity } 2 \text { of } \\
\text { 'dissolution and its } \\
\text { components' }\end{array}$ & & $\begin{array}{l}\text { Worksheet } \\
\text { with hands-on } \\
\text { activities }\end{array}$ & $\begin{array}{l}\text { 'The opposition party and the party in } \\
\text { power at National Assembly' analogy } \\
\text { and the related analogical mapping } \\
\text { table. Also, a transparent paper to } \\
\text { illustrate some sample solutions and } \\
\text { their components }\end{array}$ & \\
\hline $\begin{array}{l}\text { Activity } 3 \quad \text { of } \\
\text { 'conservation of } \\
\text { mass during } \\
\text { dissolution process' }\end{array}$ & & $\begin{array}{l}\text { Worksheet } \\
\text { with hands-on } \\
\text { activities by } \\
\text { help of Taylor } \\
\text { and Coll (12)'s } \\
\text { and Johnson } \\
\text { and Scott (8)'s } \\
\text { studies }\end{array}$ & $\begin{array}{l}\text { Demonstration experiment with calcium } \\
\text { sandoz tablet }\end{array}$ & \\
\hline $\begin{array}{l}\text { Activity } 4 \text { of } \\
\text { 'electrolyte and non- } \\
\text { electrolyte solutions' }\end{array}$ & & $\begin{array}{l}\text { Conceptual } \\
\text { change text }\end{array}$ & $\begin{array}{l}\text { Fortman (28)'s analogy and related } \\
\text { analogical mapping table }\end{array}$ & \\
\hline $\begin{array}{l}\text { Activity } 5 \text { of 'types } \\
\text { of solutions' }\end{array}$ & & $\begin{array}{l}\text { Worksheet } \\
\text { with analogies } \\
\text { and analogical } \\
\text { reasoning }\end{array}$ & $\begin{array}{l}\text { Analogical mapping table and a sample } \\
\text { question }\end{array}$ & \\
\hline $\begin{array}{l}\text { Activity } 6 \text { of 'the } \\
\text { effects } \\
\text { temperature of and } \\
\text { pressure to the } \\
\text { dissolution of a gas } \\
\text { into a liquid' }\end{array}$ & & $\begin{array}{l}\text { Worksheet } \\
\text { with hands-on } \\
\text { activities }\end{array}$ & $\begin{array}{l}\text { Three transparent papers-two of which } \\
\text { are used to help students to visualize the } \\
\text { given phenomena at sub-microscopic } \\
\text { level by means of particulate nature of } \\
\text { matter. The rest one illustrates how } \\
\text { solubility changes with temperature }\end{array}$ & \\
\hline $\begin{array}{l}\text { Activity } 7 \text { of 'the } \\
\text { effect of temperature } \\
\text { to dissolution of a } \\
\text { solid into a liquid' }\end{array}$ & & $\begin{array}{l}\text { Worksheet } \\
\text { with analogy } \\
\text { activities and } \\
\text { analogical } \\
\text { reasoning }\end{array}$ & $\begin{array}{l}\text { Analogical mapping table and a } \\
\text { transparent paper to illustrate how } \\
\text { temperature affects solubility of a solid } \\
\text { into a liquid }\end{array}$ & \\
\hline $\begin{array}{l}\text { Activity } 8 \text { 'the } \\
\text { effects of stirring } \\
\text { process and surface } \\
\text { area to the } \\
\text { dissolution }\end{array}$ & & $\begin{array}{l}\text { Worksheet } \\
\text { with analogy } \\
\text { activities and } \\
\text { analogical } \\
\text { reasoning }\end{array}$ & Analogical mapping table & \\
\hline
\end{tabular}

Table 3. One-way ANOVA's results

\begin{tabular}{|l|c|c|c|c|c|}
\hline \multicolumn{1}{|c|}{ SCORE } & Sum of Squares & df & Mean Square & F & Sig. \\
\hline Between groups & 13927,789 & 2 & 6963,895 & 78,074 & 0.000 \\
\hline Within Groups & 9900,816 & 111 & 89,197 & & \\
\hline
\end{tabular}


Table 4. Results from multiple comparisons (post-hoc)

\begin{tabular}{|r|r|r|r|}
\hline \multicolumn{2}{|l|}{$\begin{array}{l}\text { Tukey HSD } \\
\text { Score }\end{array}$} & $\begin{array}{l}\text { Mean Difference } \\
\text { (I-J) }\end{array}$ & \multicolumn{1}{l|}{ Sig. } \\
\hline (I) TEST & $(\mathrm{J})$ TEST & & \\
\hline pre-test & post-test & $-23,47$ &, 000 \\
\cline { 2 - 4 } & delayed test & $-23,42$ &, 000 \\
\hline post-test & pre-test & 23,47 &, 000 \\
\cline { 2 - 4 } & delayed test & 0,0526 & 1,000 \\
\hline delayed test & pre-test & 23,42 &, 000 \\
\cline { 2 - 4 } & post-test & $-0,0526$ & 1,000 \\
\hline
\end{tabular}

* The mean difference is significant at the .05 level.

Table 5. Frequencies and percentages of students' responses to the two-tier questions

\begin{tabular}{|c|c|c|c|c|c|c|c|c|c|c|c|c|c|c|c|c|c|c|c|c|c|c|c|c|c|}
\hline \multicolumn{2}{|c|}{ Item No. } & \multicolumn{2}{|c|}{ CCSU } & \multicolumn{2}{|c|}{ CCPU } & \multicolumn{2}{|c|}{ NCSU } & \multicolumn{2}{|c|}{ ICSU } & \multicolumn{2}{|c|}{$\mathrm{NCPU}$} & \multicolumn{2}{|c|}{ CCSAC } & \multicolumn{2}{|c|}{$\mathrm{CC}$} & \multicolumn{2}{|c|}{ ICSAC } & \multicolumn{2}{|c|}{ NCSAC } & \multicolumn{2}{|c|}{$\mathrm{IC}$} & \multicolumn{2}{|c|}{ NA } & \multicolumn{2}{|c|}{ MD } \\
\hline & & $\mathrm{N}$ & $\%$ & $\mathrm{~N}$ & $\%$ & $\mathrm{~N}$ & $\%$ & $\mathrm{~N}$ & $\%$ & $\mathrm{~N}$ & $\%$ & $\mathrm{~N}$ & $\%$ & $\mathrm{~N}$ & $\%$ & $\mathrm{~N}$ & $\%$ & $\mathrm{~N}$ & $\%$ & $\mathrm{~N}$ & $\%$ & $\mathrm{~N}$ & $\%$ & $\mathrm{~N}$ & $\%$ \\
\hline \multirow{3}{*}{ Е } & Pretest & - & - & - & - & - & - & 13 & 29,5 & 6 & 13,6 & 1 & 2,3 & 1 & 2,3 & 13 & 29,5 & 1 & 2,3 & 2 & 4,5 & 5 & 11,4 & 2 & 4,5 \\
\hline & Posttest & 12 & 27,3 & 5 & 11,4 & 1 & 2,3 & 18 & 40,9 & 2 & 4,5 & - & - & - & - & 1 & 2,3 & - & - & - & - & 3 & 6,8 & 2 & 4,5 \\
\hline & $\begin{array}{l}\text { Delayed } \\
\text { test }\end{array}$ & 7 & 15,9 & 6 & 13,6 & - & - & 24 & 54,5 & - & - & - & - & - & - & 5 & 11,4 & - & - & - & - & - & - & 2 & 4,5 \\
\hline \multirow{3}{*}{$\stackrel{\sim}{\Xi}$} & Pretest & - & - & 3 & 6,8 & - & - & - & - & - & - & 11 & 25 & 27 & 61,4 & - & - & - & - & - & - & 1 & 2,3 & 2 & 4,5 \\
\hline & Posttest & 14 & 31,8 & 16 & 36,4 & - & - & - & - & - & - & 4 & 9,1 & 8 & 18,2 & - & - & - & - & - & - & - & - & 2 & 4,5 \\
\hline & $\begin{array}{l}\text { Delayed } \\
\text { test }\end{array}$ & 2 & 4,5 & 25 & 56,8 & - & - & - & - & - & - & 6 & 13,6 & 9 & 20,5 & - & - & - & - & - & - & - & - & 2 & 4,5 \\
\hline \multirow{3}{*}{$\stackrel{\Xi}{\Xi}$} & Pretest & - & - & 5 & 11,4 & - & - & - & - & - & - & 9 & 20,5 & 5 & 11,4 & 12 & 27,3 & 1 & 2,3 & 1 & 2,3 & 9 & 20,5 & 2 & 4,5 \\
\hline & Posttest & 10 & 22,7 & 24 & 54,5 & - & - & - & - & - & - & 4 & 9,1 & - & - & 3 & 6,8 & - & - & 1 & 2,3 & - & - & 2 & 4,5 \\
\hline & $\begin{array}{l}\text { Delayed } \\
\text { test }\end{array}$ & 4 & 9,1 & 30 & 68,2 & - & - & - & - & - & - & 4 & 9,1 & 1 & 2,3 & 2 & 4,5 & - & - & - & - & 1 & 2,3 & 2 & 4,5 \\
\hline \multirow{3}{*}{$\begin{array}{l}0 \\
\Xi \\
\Xi \\
\Xi\end{array}$} & Pretest & 1 & 2,3 & 9 & 20,5 & - & - & - & - & - & - & 17 & 38,6 & 1 & 2,3 & 8 & 18,2 & 1 & 2,3 & 4 & 9,1 & 1 & 2,3 & 2 & 4,5 \\
\hline & Posttest & 7 & 15,9 & 16 & 36,4 & - & - & 1 & 2,3 & - & - & 5 & 11,4 & - & - & 10 & 22,7 & - & - & 1 & 2,3 & 2 & 4,5 & 2 & 4,5 \\
\hline & $\begin{array}{l}\text { Delayed } \\
\text { test }\end{array}$ & 5 & 11,4 & 13 & 29,5 & - & - & - & - & - & - & 7 & 15,9 & - & - & 17 & 38,6 & - & - & - & - & - & - & 2 & 4,5 \\
\hline \multirow{3}{*}{$\stackrel{\nabla}{\Xi}$} & Pretest & - & - & 6 & 13,6 & - & - & - & - & - & - & 8 & 18,2 & 6 & 13,6 & 13 & 29,5 & - & - & 7 & 15,9 & 2 & 4,5 & 2 & 4,5 \\
\hline & Posttest & 2 & 4,5 & 9 & 20,5 & - & - & - & - & - & - & 4 & 9,1 & - & - & 19 & 43,2 & - & - & 4 & 9,1 & 4 & 9,1 & 2 & 4,5 \\
\hline & $\begin{array}{l}\text { Delayed } \\
\text { test }\end{array}$ & - & - & 11 & 25 & - & - & - & - & - & - & 4 & 9,1 & - & - & 25 & 56,8 & - & - & - & - & 2 & 4,5 & 2 & 4,5 \\
\hline \multirow{3}{*}{$\begin{array}{l}\infty \\
\stackrel{\Xi}{ \pm}\end{array}$} & Pretest & 1 & 2,3 & 17 & 38,6 & - & - & - & - & 1 & 2,3 & 3 & 6,8 & 10 & 22,7 & 6 & 13,6 & - & - & 1 & 2,3 & 3 & 6,8 & 2 & 4,5 \\
\hline & Posttest & 7 & 15,9 & 31 & 70,5 & - & - & - & - & - & - & - & - & 1 & 2,3 & 2 & 4,5 & - & - & - & - & 1 & 2,3 & 2 & 4,5 \\
\hline & $\begin{array}{l}\text { Delayed } \\
\text { test }\end{array}$ & 5 & 11,4 & 33 & 75 & - & - & - & - & - & - & - & - & - & - & 4 & 9,1 & - & - & - & - & - & - & 2 & 4,5 \\
\hline \multirow{3}{*}{$\begin{array}{l}\stackrel{a}{ \pm} \\
\pm\end{array}$} & Pretest & 1 & 2,3 & 13 & 29,5 & - & - & - & - & - & - & - & - & 2 & 4,5 & 16 & 36,4 & - & - & 2 & 4,5 & 8 & 18,2 & 2 & 4,5 \\
\hline & Posttest & 4 & 9,1 & 21 & 47,7 & - & - & - & - & - & - & 1 & 2,3 & 1 & 2,3 & 11 & 25 & - & - & - & - & 4 & 9,1 & 2 & 4,5 \\
\hline & $\begin{array}{l}\text { Delayed } \\
\text { test }\end{array}$ & 2 & 4,5 & 24 & 54,5 & - & - & - & - & - & - & 1 & 2,3 & - & - & 13 & 29,5 & - & - & - & - & 2 & 4,5 & 2 & 4,5 \\
\hline
\end{tabular}

CCSU: Correct Choice with Sound Understanding, CCPU: Correct Choice with Partial Understanding, NCSU: No

Choice with Sound Understanding, ICSU: Incorrect Choice with Sound Understanding, NCPU: No Choice with

Partial Understanding, CCSAC: Correct Choice with Specific Alternative Conception, CC: Correct Choice, ICSAC:

Incorrect Choice with Specific Alternative Conception, NCSAC: No Choice with Specific Alternative Conception,

IC: Incorrect Choice, NR: No response or Irrelevant Responses; MD: Missing data incorporates student who did not

participate the test. 
Table 6. Frequencies and percentages of students' responses to directly open-ended questions

\begin{tabular}{|c|c|c|c|c|c|c|c|c|c|c|c|c|c|}
\hline \multicolumn{2}{|c|}{ Item No. } & \multicolumn{2}{|c|}{ SU } & \multicolumn{2}{|c|}{ PU } & \multicolumn{2}{|c|}{ PUSAC } & \multicolumn{2}{|c|}{ SAC } & \multicolumn{2}{|c|}{ NU } & \multicolumn{2}{|c|}{ MD } \\
\hline & & $\mathrm{N}$ & $\%$ & $\mathrm{~N}$ & $\%$ & $\mathrm{~N}$ & $\%$ & $\mathrm{~N}$ & $\%$ & $\mathrm{~N}$ & $\%$ & $\mathrm{~N}$ & $\%$ \\
\hline \multirow{3}{*}{$\begin{array}{l}\text { m } \\
\text { E } \\
\text { E }\end{array}$} & Pretest & - & - & 6 & 13,6 & 20 & 45,5 & 9 & 20,5 & 7 & 15,9 & 2 & 4,5 \\
\hline & Posttest & 16 & 36,4 & 17 & 38,6 & 8 & 18,2 & 1 & 2,3 & - & - & 2 & 4,5 \\
\hline & $\begin{array}{l}\text { Delayed } \\
\text { test }\end{array}$ & 11 & 25 & 20 & 45,5 & 11 & 25 & - & - & - & - & 2 & 4,5 \\
\hline \multirow{3}{*}{$\begin{array}{l}n \\
\stackrel{\Xi}{ \pm} \\
\stackrel{E}{ \pm}\end{array}$} & Pretest & - & - & 10 & 22,7 & 1 & 2,3 & 2 & 4,5 & 29 & 65,9 & 2 & 4,5 \\
\hline & Posttest & 2 & 4,5 & 14 & 31,8 & - & - & 4 & 9,1 & 22 & 50 & 2 & 4,5 \\
\hline & $\begin{array}{l}\text { Delayed } \\
\text { test }\end{array}$ & 6 & 13,6 & 10 & 22,7 & 1 & 2,3 & 2 & 4,5 & 23 & 52,3 & 2 & 4,5 \\
\hline \multirow{3}{*}{$\begin{array}{l}\Xi \\
\Xi \\
\Xi \\
\Xi\end{array}$} & Pretest & - & - & 8 & 18,2 & 3 & 6,8 & 9 & 20,5 & 22 & 50 & 2 & 4,5 \\
\hline & Posttest & 1 & 2,3 & 35 & 79,5 & 2 & 4,5 & 3 & 6,8 & 1 & 2,3 & 2 & 4,5 \\
\hline & $\begin{array}{l}\text { Delayed } \\
\text { test }\end{array}$ & - & - & 39 & 88,6 & 1 & 2,3 & 1 & 2,3 & 1 & 2,3 & 2 & 4,5 \\
\hline \multirow{3}{*}{ 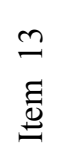 } & Pretest & - & - & 15 & 34,1 & - & - & 4 & 9,1 & 23 & 52,3 & 2 & 4,5 \\
\hline & Posttest & - & - & 27 & 61,4 & 2 & 4,5 & 2 & 4,5 & 11 & 25 & 2 & 4,5 \\
\hline & $\begin{array}{l}\text { Delayed } \\
\text { test }\end{array}$ & - & - & 30 & 68,2 & 3 & 6,8 & 3 & 6,8 & 6 & 13,6 & 2 & 4,5 \\
\hline
\end{tabular}

SU: Sound Understanding, PU: Partial Understanding, PUSAC: Partial Understanding with Specific Alternative Conception, SAC: Specific Alternative Conceptions, NU: No Understanding, MD: Missing data incorporates student who did not participate the test.

Table 7. Students' responses to principal questions in sugar/water system

\begin{tabular}{|c|c|c|}
\hline Questions & Student's response & Student's number \\
\hline $\begin{array}{l}\text { What happens when you add sugar } \\
\text { into a beaker of water }\end{array}$ & Dissolution process takes place & S6, S8, S9, S16, S25 and S42 \\
\hline \multirow{5}{*}{ What do you mean by 'dissolution'? } & $\begin{array}{l}\text { Sugar decomposes to its own ions } \\
\text { and disperses in water }\end{array}$ & S25 \\
\hline & $\begin{array}{l}\text { Sugar that is a solid matter dissolves } \\
\text { into water that is solvent }\end{array}$ & S8 \\
\hline & $\begin{array}{l}\text { Both solid's and liquid's particles } \\
\text { mix with each other fully }\end{array}$ & S6 \\
\hline & $\begin{array}{l}\text { A solution emerges in an } \\
\text { environment involving in solute and } \\
\text { solvent }\end{array}$ & S9 \\
\hline & $\begin{array}{l}\text { Dissolution means that a solid } \\
\text { decomposes to either its own ions or } \\
\text { its own molecules into a liquid }\end{array}$ & S16, S42 \\
\hline $\begin{array}{l}\text { Do you mean that if a solution } \\
\text { generates, it must consist of a solid } \\
\text { and a liquid? }\end{array}$ & $\begin{array}{l}\text { No, it is not an obligation. Gas-gas, } \\
\text { liquid-gas, solid-gas etc. are also } \\
\text { possible }\end{array}$ & S6, S8, S9, S16, S25, S42 \\
\hline $\begin{array}{l}\text { Could you explain the type of } \\
\text { mixture constituted? }\end{array}$ & $\begin{array}{l}\text { It is a homogenous mixture whose } \\
\text { properties are equal everywhere }\end{array}$ & S6, S8, S9, S16, S25, S42 \\
\hline $\begin{array}{l}\text { What do you think about the } \\
\text { generated solution, i.e., whether it is } \\
\text { a new compound which differ from } \\
\text { its first components? }\end{array}$ & $\begin{array}{l}\text { It is not a new compound differing } \\
\text { from its first components }\end{array}$ & S6, S8, S9, S16, S25, S42 \\
\hline Please explain your reason & $\begin{array}{l}\text { We can obtain the initial } \\
\text { components by means of physical }\end{array}$ & S6, S8, S16, S42 \\
\hline
\end{tabular}




\begin{tabular}{|c|c|c|}
\hline & ways & \multirow[b]{2}{*}{ S9 } \\
\hline & $\begin{array}{l}\text { Since it is a homogenous mixture, } \\
\text { we cannot represent it with a } \\
\text { different chemical formula. Because } \\
\text { the same components are already } \\
\text { available in solution so that we can } \\
\text { feel sugar by tasting }\end{array}$ & \\
\hline & $\begin{array}{l}\text { We can obtain the initial } \\
\text { components using physical ways }\end{array}$ & S25 \\
\hline \multirow[t]{3}{*}{$\begin{array}{l}\text { Could you explain which of the } \\
\text { changes occurs here, physical or } \\
\text { chemical }\end{array}$} & $\begin{array}{l}\text { Physical change because the initial } \\
\text { components can be obtained } \\
\text { physically }\end{array}$ & S6, S8, S16, S42 \\
\hline & $\begin{array}{l}\text { Chemical change because a new } \\
\text { compound does not appear }\end{array}$ & S9 \\
\hline & $\begin{array}{l}\text { Chemical change because sugar in } \\
\text { water can be obtained by means of } \\
\text { chemical ways }\end{array}$ & S25 \\
\hline \multirow[t]{4}{*}{ Please explain your drawn figures } & $\begin{array}{l}\text { There are air gaps in water and sugar } \\
\text { fills them }\end{array}$ & S6 \\
\hline & $\begin{array}{l}\text { Sugar and water mix with one } \\
\text { another }\end{array}$ & S8 \\
\hline & They mix everywhere in water & S9 \\
\hline & $\begin{array}{l}\begin{array}{l}\text { They mix with each other } \\
\text { homogenously }\end{array} \\
\end{array}$ & S16, S25, S42 \\
\hline How does sugar mix with water? & Homogenously & S6, S8, S9, S16, S25, S42 \\
\hline Does your drawn figure reflect this? & It reflects homogenous mixture & S6, S8, S9, S16, S25, S42 \\
\hline \multirow{2}{*}{$\begin{array}{l}\text { Do you think that the total mass of } \\
\text { solution is equal to the initial masses } \\
\text { of components (sugar and water)? }\end{array}$} & Total mass does not conserve & S6, S16, S42 \\
\hline & Total mass conserves & S8, S9, S25 \\
\hline \multirow[t]{5}{*}{ Please defend your responses } & $\begin{array}{l}\text { Because of filling the gaps there is a } \\
\text { little decrease and total mass of } \\
\text { sugar in water increases, too. }\end{array}$ & S6 \\
\hline & $\begin{array}{l}\text { In dispersing sugar, there is a little } \\
\text { difference due to the gaps }\end{array}$ & S16, S42 \\
\hline & $\begin{array}{l}\text { Both of the total masses of them are } \\
\text { the same because water cause to lose } \\
\text { the properties of sugar and there is a } \\
\text { matter loss }\end{array}$ & S8 \\
\hline & $\begin{array}{l}\text { They disperse homogenously and } \\
\text { are equal to the total mass of the } \\
\text { initial components }\end{array}$ & S9 \\
\hline & $\begin{array}{l}\text { There is no gap between sugar and } \\
\text { water particles }\end{array}$ & S25 \\
\hline $\begin{array}{l}\text { If you vaporize water in solution } \\
\text { fully, what happens? }\end{array}$ & $\begin{array}{l}\text { Sugar is re-obtained or stays at the } \\
\text { bottom as initial condition }\end{array}$ & S6, S8, S9, S16, S25, S42 \\
\hline \multirow{4}{*}{$\begin{array}{l}\text { Please explain the reason why water } \\
\text { vaporize rather than sugar }\end{array}$} & $\begin{array}{l}\text { Sugar is not a volatile matter. } \\
\text { Liquids such as water, alcohol etc. } \\
\text { vaporize. However, to vaporize } \\
\text { sugar it must be liquefied }\end{array}$ & S6 \\
\hline & $\begin{array}{l}\text { There is a physical change so that } \\
\text { sugar can be re-obtained }\end{array}$ & S8 \\
\hline & $\begin{array}{l}\text { Since water comprises of gas } \\
\text { matters, it touches with those }\end{array}$ & S9 \\
\hline & $\begin{array}{l}\text { Since water is in liquid phase, its } \\
\text { vaporization is easier than a solid }\end{array}$ & $\mathrm{S} 16, \mathrm{~S} 25, \mathrm{~S} 42$ \\
\hline
\end{tabular}




\begin{tabular}{|c|c|c|}
\hline & $\begin{array}{l}\text { one that must be liquefied and then } \\
\text { vaporized }\end{array}$ & \\
\hline $\begin{array}{l}\text { Taking into consideration the } \\
\text { foregoing solution (sugar in water), } \\
\text { which one is solute and which one is } \\
\text { solvent }\end{array}$ & Sugar is solute and water is solvent & S6, S8, S9, S16, S25, S42 \\
\hline $\begin{array}{l}\text { What do you mean by the term } \\
\text { 'solvent'? }\end{array}$ & $\begin{array}{l}\text { The amount of solvent in solution is } \\
\text { more than that of solute }\end{array}$ & S6, S8, S9, S16, S25, S42 \\
\hline $\begin{array}{l}\text { What do you mean by the term } \\
\text { 'solute'? }\end{array}$ & $\begin{array}{l}\text { The amount of solute in solution is } \\
\text { less than that of solvent }\end{array}$ & S6, S8, S9, S16, S25, S42 \\
\hline \multirow{4}{*}{$\begin{array}{l}\text { (After heating one of the beakers) } \\
\text { please explain what you observed }\end{array}$} & Sugar dropped dissolves rapidly & S6 \\
\hline & Rate of dissolution increases & $\mathrm{S} 16, \mathrm{~S} 25$ \\
\hline & $\begin{array}{l}\text { The amount of the dissolved solute } \\
\text { boasts }\end{array}$ & S9, S42 \\
\hline & No response (quietness) & S8 \\
\hline \multirow{3}{*}{$\begin{array}{l}\text { Please explain how temperature } \\
\text { affects the amount of the dissolved } \\
\text { solute in solution (for a solid into a } \\
\text { liquid) }\end{array}$} & $\begin{array}{l}\text { It does not influence the amount of } \\
\text { the dissolved solute. It only affects } \\
\text { rate of dissolution }\end{array}$ & S6, S25 \\
\hline & $\begin{array}{l}\text { It increases the amount of the } \\
\text { dissolved solute }\end{array}$ & S9, S16, S45 \\
\hline & $\begin{array}{l}\text { Whilst the amount of the solute } \\
\text { staying at the bottom entails and the } \\
\text { amount of the dissolved solute } \\
\text { increases, as well }\end{array}$ & S8 \\
\hline \multirow[t]{2}{*}{$\begin{array}{l}\text { Do you consider as to whether or not } \\
\text { sugar in water conducts electricity? }\end{array}$} & $\begin{array}{l}\text { Sugar in water does not conduct } \\
\text { electricity }\end{array}$ & S6, S8, S9, S16, S42 \\
\hline & Sugar in water conducts electricity & S25 \\
\hline \multirow[t]{4}{*}{ Please defend your response } & $\begin{array}{l}\text { Sugar decomposes to their own } \\
\text { particles at molecular level, not } \\
\text { incorporate in ions }\end{array}$ & S9, S16 \\
\hline & There is no ion in solution & S6, S42 \\
\hline & $\begin{array}{l}\text { Sugar in water does not have such a } \\
\text { feature that conducts the electricity }\end{array}$ & S8 \\
\hline & $\begin{array}{l}\text { Since sugar decomposes to its own } \\
\text { ions it does not conduct electricity. } \\
\text { In fact, all solutions conduct the } \\
\text { electricity }\end{array}$ & S25 \\
\hline $\begin{array}{l}\text { Could you give a solution example } \\
\text { that conducts the electricity? }\end{array}$ & Salt in water & S6, S8, S9, S16, S25, S42 \\
\hline
\end{tabular}

Table 8. Students' responses to principal questions in olive oil/alcohol/water system

\begin{tabular}{|l|l|l|}
\hline Questions & Student's response & Student's number \\
\hline $\begin{array}{l}\text { (after adding a little ethyl alcohol } \\
\text { into water) please explain what } \\
\text { happens }\end{array}$ & \begin{tabular}{l} 
Ethyl alcohol disperse \\
\cline { 2 - 3 } \\
$\begin{array}{l}\text { Ethyl alcohol interacts with water } \\
\text { and then a solution yields as result } \\
\text { of their mixing }\end{array}$
\end{tabular} \\
\cline { 2 - 3 } & Ethyl alcohol dissolves & S9 \\
\cline { 2 - 3 } & $\begin{array}{l}\text { Ethyl alcohol mixes in water } \\
\text { homogenously }\end{array}$ & S16 \\
\cline { 2 - 3 } & A solution emerges & S25 \\
\hline
\end{tabular}




\begin{tabular}{|c|c|c|}
\hline \multirow{2}{*}{$\begin{array}{l}\text { How does alcohol disperse into } \\
\text { water? }\end{array}$} & Homogenously & S6, S9, S16, S25, S42 \\
\hline & $\begin{array}{l}\text { Since ethyl alcohol disperses with } \\
\text { another liquid such as water, they } \\
\text { mix with each other } \\
\text { heterogeneously. Due to density, } \\
\text { ethyl alcohol stays at the bottom and } \\
\text { water locates at the top }\end{array}$ & S8 \\
\hline $\begin{array}{l}\text { (after pouring a little olive oil into } \\
\text { ethyl alcohol in water) please } \\
\text { explain what happens }\end{array}$ & $\begin{array}{l}\text { Olive oil goes up the top of the } \\
\text { beaker }\end{array}$ & S6, S8, S9, S16, S25, S42 \\
\hline \multirow{2}{*}{$\begin{array}{l}\text { Why does the olive oil go up the top } \\
\text { of the beaker? }\end{array}$} & The reason is its density & S6, S8, S9, S16, S42 \\
\hline & $\begin{array}{l}\text { Since a heterogenic solution occurs, } \\
\text { ethyl alcohol and water mix with } \\
\text { each other and olive oil goes up the } \\
\text { top of the beaker }\end{array}$ & $\mathrm{S} 25$ \\
\hline \multirow[t]{5}{*}{$\begin{array}{l}\text { Do you think that the only reason is } \\
\text { density for olive oil? }\end{array}$} & $\begin{array}{l}\text { Olive oil mixes neither ethyl alcohol } \\
\text { nor water }\end{array}$ & S6, S25 \\
\hline & $\begin{array}{l}\text { Ethyl alcohol and water yield a } \\
\text { solution and olive oil does not mix } \\
\text { them }\end{array}$ & S9 \\
\hline & $\begin{array}{l}\text { Olive oil does not mix with ethyl } \\
\text { alcohol and water homogenously }\end{array}$ & S16 \\
\hline & $\begin{array}{l}\text { Olive oil does not dissolve with } \\
\text { ethyl alcohol and water. However, it } \\
\text { can dissolve another matter which } \\
\text { has similar properties }\end{array}$ & S42 \\
\hline & The only reason is its density & S8 \\
\hline \multirow[t]{2}{*}{ Please explain your drawn figure } & $\begin{array}{l}\text { Ethyl alcohol and water disperse } \\
\text { with each other homogenously and } \\
\text { olive oil goes up the top of beaker }\end{array}$ & S6, S9, S16, S25, S42 \\
\hline & $\begin{array}{l}\text { Ethyl alcohol interacts with water } \\
\text { and yields heterogenic mixture. } \\
\text { Since olive oil's density is less than } \\
\text { those of the others, it stays at the top } \\
\text { and occurs a heterogenic mixture }\end{array}$ & S8 \\
\hline \multirow{2}{*}{$\begin{array}{l}\text { Do you think that the total mass of } \\
\text { 'olive oil/ethyl alcohol/water' } \\
\text { system is equal to total of the initial } \\
\text { masses of components (olive oil, } \\
\text { ethyl alcohol and water)? }\end{array}$} & $\begin{array}{l}\text { The total mass of the system is not } \\
\text { equal }\end{array}$ & S6, S8, S16, S42 \\
\hline & The total mass of the system is equal & S9, S25 \\
\hline \multirow[t]{4}{*}{ Please defend your response } & $\begin{array}{l}\text { Ethyl alcohol fills the gaps into } \\
\text { water }\end{array}$ & S6, S16, S42 \\
\hline & $\begin{array}{l}\text { Since ethyl alcohol and water } \\
\text { constitute a heterogenic mixture, } \\
\text { there is a decrease in the total mass } \\
\text { of the system }\end{array}$ & S8 \\
\hline & $\begin{array}{l}\text { Olive oil does not mix and the total } \\
\text { mass of the system does not change }\end{array}$ & S9 \\
\hline & No response (quietness) & $\mathrm{S} 25$ \\
\hline \multirow[t]{2}{*}{$\begin{array}{l}\text { Please address the solute and solvent } \\
\text { in this system }\end{array}$} & $\begin{array}{l}\text { Water is solvent and ethyl alcohol is } \\
\text { solute }\end{array}$ & S6, S9, S16, S25, S42 \\
\hline & $\begin{array}{l}\text { Since there is a heterogenic mixture, } \\
\text { we cannot mention from solute and } \\
\text { solvent }\end{array}$ & S8 \\
\hline What do you mean by the term & The amount of the solvent in & S6, S8, S9, S16, S42 \\
\hline
\end{tabular}




\begin{tabular}{|l|l|l|}
\hline 'solvent'? & solution is more & \\
\cline { 2 - 3 } & $\begin{array}{l}\text { Solvent dissolves a matter by } \\
\text { decomposing it to its own ions }\end{array}$ & S25 \\
\hline $\begin{array}{l}\text { What do you mean by the term } \\
\text { 'solute'? }\end{array}$ & $\begin{array}{l}\text { The amount of solute in solution is } \\
\text { less than that of solvent }\end{array}$ & S6, S8, S9, S16, S42 \\
\cline { 2 - 3 } & $\begin{array}{l}\text { Solute decomposes to its own ions } \\
\text { and disperses everywhere } \\
\text { homogenously }\end{array}$ & S25 \\
\hline
\end{tabular}

